CLINICAL REVIEW

\title{
Sleep disorders and Parkinson disease; lessons from genetics
}

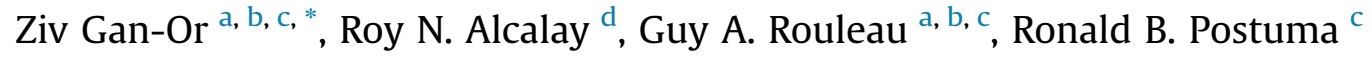 \\ a Montreal Neurological Institute, McGill University, Montréal, QC, Canada \\ b Department of Human Genetics, McGill University, Montréal, QC, Canada \\ ${ }^{c}$ Department of Neurology and Neurosurgery, McGill University, Montréal, QC, Canada \\ d Department of Neurology, Taub Institute for Research on Alzheimer's Disease and the Aging Brain, College of Physicians and Surgeons, Columbia \\ University, New York, NY, USA
}

\section{A R T I C L E I N F O}

\section{Article history:}

Received 1 August 2016

Received in revised form 4 October 2017

Accepted 15 January 2018

Available online 31 January 2018

\section{Keywords:}

Rapid eye movement sleep behavior

disorder

RBD

Restless legs syndrome

RLS

Parkinson disease

Neurodegeneration

Genetics

Glucocerebrosidase

GBA

\begin{abstract}
S U M M A R Y
Parkinson disease is a common, age-related neurodegenerative disorder, projected to afflict millions of individuals in the near future. Understanding its etiology and identifying clinical, genetic or biological markers for Parkinson disease onset and progression is therefore of major importance. Various sleeprelated disorders are the most common group of non-motor symptoms in advanced Parkinson disease, but they can also occur during its prodromal phase. However, with the exception of REM sleep behavior disorder, it is unclear whether they are part of the early pathological process of Parkinson disease, or if they develop as Parkinson disease advances because of treatments and neurodegeneration progression. The advancements in genetic studies in the past two decades have generated a wealth of information, and recent genetic studies offer new insight on the association of sleep-related disorders with Parkinson disease. More specifically, comparing genetic data between Parkinson disease and sleep-related disorders can clarify their association, which may assist in determining whether they can serve as clinical markers for Parkinson disease risk or progression. In this review, we discuss the current knowledge on the genetics of sleep-related disorders in Parkinson disease context, and the potential implications on research, diagnosis, counseling and treatment.
\end{abstract}

๑) 2018 Elsevier Ltd. All rights reserved.

\section{Introduction}

As the world's population ages, age-related disorders such as Parkinson disease (PD) threaten to become a significant financial and social burden [1], on top of the personal burden carried by the affected individuals and their families. PD is the most common neurodegenerative movement disorder, affecting $1-2 \%$ of the population older than $60 \mathrm{y}$ [2-4], and the projected number of PD patients in 2030 in 15 of the most populous nations is estimated to be 8.67 million patients [5]. PD is pathologically characterized by degeneration of the substantia nigra (SN) and the presence of Lewy bodies, which are aggregates of various proteins, primarily $\alpha$-synuclein [6]. As such, it is part of a family of disorders collectively termed synucleinopathies, mainly including PD, dementia with Lewy bodies (DLB), and multiple system atrophy (MSA) [7]. Other

\footnotetext{
* Corresponding author. Montreal Neurological Institute and hospital, The Department of Human Genetics, McGill University, 1033 Pine Avenue, West, Ludmer Pavilion, Room 327, Montreal, QC, H3A 1A1. Fax: +1 5143988248.

E-mail address: ziv.gan-or@mail.mcgill.ca (Z. Gan-Or).
}

diseases may also have $\alpha$-synuclein depositions, and while this is a shared feature, it does not imply that $\alpha$-synuclein is the sole cause for these disorders.

The pathogenic process leading to PD begins many years before diagnosis, which is traditionally based on classical motor symptoms; therefore, the course of PD can be divided accordingly, to preclinical PD, prodromal PD (non-motor PD) and clinical PD, when motor symptoms appear [8]. This recent division aims to distinguish between the different phases of PD, first, when neurodegeneration started but no symptoms are present (preclinical PD), then when early symptoms appear but PD is not diagnosed yet (prodromal PD), and lastly when motor symptoms present (clinical PD) [8]. Clinical PD occurs when about half of the dopaminergic neurons in the SN had already been irreversibly degenerated and died, and the typical motor symptoms appear [9]. One of the main challenges in PD research is identifying individuals during the prodromal phase of PD; when neuroprotective therapy is available, early diagnosis of PD will be crucial to slow or stop the degenerative process prior to motor parkinsonism. 


\section{Glossary of terms}

Genome-wide association study

A case-control study that examines the frequencies of common single nucleotide polymorphisms across the human genome and compares these frequencies between patients and controls. Significant differences in frequencies, after correcting for multiple comparisons, may suggest an association between genes in the regions of these polymorphism and susceptibility to a disease

Pleiotropy When a single genetic variant, gene or locus contribute to more than one phenotype

\section{Abbreviations}

DLB Dementia with Lewy bodies

EDS Excessive daytime sleepiness

GWAS Genome wide association study

MSA Multiple system atrophy

OMIM Online Mendelian Inheritance in Man

OR odds ratio

OSA Obstructive sleep apnea

PD Parkinson disease

PLMS Periodic leg movement in sleep

RBD REM sleep behavior disorder

REM Rapid eye movement

RLS Restless legs syndrome

SN Substantia nigra

Sleep-related disorders are, as a group, the most common nonmotor features of PD. Insomnia, fragmentation of sleep, and excessive daytime sleepiness (EDS) are experienced by more than $50 \%$ of PD patients in some studies [10,11]. During the prodromal phase of $\mathrm{PD}$, rapid eye movement (REM) sleep behavior disorder (RBD) [12-15], restless legs syndrome (RLS) [16] EDS [17,18], and other sleep-related disorders may already be present. If these disorders are indeed a part of the early pathogenic process of PD, they can potentially help identify individuals at-risk for PD. While the association between RBD and PD is well established [15,19], it is still under debate whether people with RLS and EDS are at increased risk for clinical PD $[10,17,20]$. Other sleep disorders, including periodic leg movement in sleep (PLMS), obstructive sleep apnea (OSA), insomnia and circadian sleep-wake cycle disruption also occur in PD [21]. However, it is not clear if these disorders represent a part of the intrinsic pathogenic process of PD, or they simply cooccur due to other factors.

During the recent decades, the rapid development of various genetic methods have led to a wealth of genetic information on familial and sporadic PD. Mutations in genes such as GBA, LRRK2, SNCA, PARK2, PINK1, PARK7, VPS35, SMPD1 and others can lead to PD [22], and at least 45 additional risk factors in 41 genetic loci were associated with increased or decreased risk for PD in genome wide association studies (GWAS) $[23,24]$. Similarly, genetic studies of sleep-related disorders have identified multiple genes and loci associated with both increased and decreased risk for these disorders. For example, GWASs of RLS cohorts identified genetic loci that are associated with the risk for RLS [25], and several studies examined the genetic overlap between RLS and PD [26-29]. Only recently, the first genetic studies of RBD were performed [30-32] in order to examine whether RBD and PD share a similar genetic background.

The purpose of this review, is first to briefly summarize the clinical associations between PD and sleep-related disorders commonly affecting PD patients. This part will map possible clinical overlaps between PD and sleep-related disorders, which may suggest possible shared etiology. Then, we will discuss the available genetic knowledge on PD and the various sleep disorders potentially associated with PD. By comparing the known genetic factors associated with PD and sleep disorders, we will discuss on the potential overlap in genetics, as an indicator for etiology. We will further discuss the implications of these data on our understanding of PD, its clinical course and future aspects.

\section{Determining the temporal correlates of sleep disorders and Parkinson disease}

The majority of PD patients will suffer from a sleep-related disorder, whether before or after the onset of PD [21]. Defining the temporal association between these sleep-related disorders and PD is important for determining whether sleep disorders can be clinical markers for PD development and/or progression. Based upon pathoanatomical considerations, essentially all sleep-related disorders could occur during prodromal PD, yet to determine if they are pathophysiologically associated with PD or just co-occur due to other factors or to chance alone, several approaches can be taken. One approach is to examine if a certain sleep-related disorder is more common in prodromal PD compared to the general population. Since it is currently difficult to identify individuals with prodromal PD, sleep-related disorders can be determined retrospectively, which may be affected by recall bias. Examining for sleep-related disorders immediately upon the diagnosis of PD may reduce the recall bias and have more reliable results (although this is no longer in prodromal stages). Another, more reliable approach is to prospectively follow-up cohorts of individuals with sleep disorders and to examine whether they develop PD at higher rates than the general population. These studies are more difficult to perform, and therefore less common. Based on these approaches, Table 1 summarizes the main temporal correlates between sleeprelated disorders and $\mathrm{PD}$, and other important clinical associations in PD.

\section{Sleep disorders in Parkinson disease - main clinical correlates}

\section{REM sleep behavior disorder}

Thus far, the only sleep-related disorder that is unequivocally associated with later development of PD and other synucleinopathies is RBD. RBD is characterized by lack of atonia during REM sleep and acting out of dreams [15,33]. After the initial report on high conversion rates from RBD to synucleinopathies [14], various reports had confirmed that individuals with RBD are likely to progress to an overt synucleinopathy in a time-dependent manner [15,19,34-37]. Fig. 1 depicts the risk for conversion to a neurodegenerative disease among patients with idiopathic RBD, ranging between $8.5 \%$ and $41 \%$ at follow-up of less than $5 \mathrm{y}$, and between $52.4 \%$ and $92.5 \%$ at follow-up of more than $10 \mathrm{y}$. The average time from onset of RBD to onset of synucleinopathy was estimated at $12 \mathrm{y}$ [38], and the prevalence of RBD at the population level was estimated at $0.3 \%-1.15 \%[39,40]$. Similar to PD, male gender is associated with RBD, with male:female ratio between 2:1 up to 8:1 in different studies; whether this reflects a true biologic association or a presentation bias (e.g., if men tend to have more violent dreams than women, which may increase the detection rate in men compared to women) is unclear [15,37]. Among PD patients, RBD can be found in $25 \%-50 \%[41,42]$, and the presence of RBD is associated with higher and faster rates of cognitive decline and dementia in PD [43], hallucinations [44], autonomic dysfunction, color vision impairment [45] and higher 
Table 1

Summary of temporal and clinical correlates of sleep-related disorders and Parkinson's disease.

\begin{tabular}{|c|c|c|c|}
\hline Sleep disorder & Prodromal PD & Motor PD & Other clinical correlates in PD \\
\hline $\begin{array}{l}\text { REM sleep behavior } \\
\text { disorder }\end{array}$ & $\begin{array}{l}\text { - More than } 80 \% \text { of RBD patients will } \\
\text { develop a synucleinopathy in a time } \\
\text { dependent manner. } \\
\text { - Dream enactment and RBD are common in } \\
\text { newly diagnosed PD patient. }\end{array}$ & $\begin{array}{l}\text { - RBD can occur after the onset of PD, and } \\
\text { the rates of PD patients with RBD increases } \\
\text { with disease duration. } \\
\text { - } 25 \%-50 \% \text { of PD patients have RBD. } \\
\text { - Possibly associated with faster motor } \\
\text { progression and higher doses of levodopa. } \\
\text { - REM sleep without atonia, which does not } \\
\text { fulfill all criteria for RBD, is also more } \\
\text { common in PD than in controls. }\end{array}$ & $\begin{array}{l}\text { - Associated with cognitive decline, } \\
\text { dementia and hallucinations. } \\
\text { - Associated with autonomic dysfunction. }\end{array}$ \\
\hline $\begin{array}{l}\text { Restless legs } \\
\text { syndrome }\end{array}$ & $\begin{array}{l}\text { - No evidence that individuals with } \\
\text { longstanding RLS develop PD at higher rates } \\
\text { than individuals without RLS. } \\
\text { - Late-onset RLS possibly may be prodromal } \\
\text { sign of PD. } \\
\text { - Contradictory results in newly diagnosed } \\
\text { PD. }\end{array}$ & $\begin{array}{l}\text { - Contradictory results, some studies } \\
\text { suggest higher rates of RLS in PD, while } \\
\text { others demonstrate similar rates to } \\
\text { controls. } \\
\text { - Estimates may be confounded by non- } \\
\text { specific motor symptoms. } \\
\text { - When PD and RLS co-occur, PD symptoms } \\
\text { usually precede RLS symptoms. }\end{array}$ & $\begin{array}{l}\text { - RLS was associated with depression in PD. } \\
\text { - associated with DBS, possibly due to } \\
\text { reduction of dopaminergic treatment. } \\
\text { - Duration of antiparkinson therapy may } \\
\text { strongly contributes to of RLS in PD, could } \\
\text { be related to "wearing off". } \\
\text { - Patients with RLS did not have } \alpha \text {-synuclein } \\
\text { pathology. } \\
\text { - RLS patients did not have increased } \\
\text { echogenicity of the substantia nigra on } \\
\text { sonography, a finding that is typical of PD. } \\
\text { - Other imaging studies in RLS patients did } \\
\text { not support overlap with PD. }\end{array}$ \\
\hline $\begin{array}{l}\text { Periodic leg movement } \\
\text { in sleep }\end{array}$ & $\begin{array}{l}\text { - No evidence that PLMS precede PD, and } \\
\text { similar PLMS index in newly diagnosed PD } \\
\text { patients vs. controls. }\end{array}$ & $\begin{array}{l}\text { - Similar frequency of PLMS in PD patients } \\
\text { and controls. } \\
\text { - Can occur after reduction in dopaminergic } \\
\text { treatment following deep brain stimulation } \\
\text { surgery. } \\
\text { - Possibly associated with striatal } \\
\text { dopaminergic nerve loss. }\end{array}$ & $\begin{array}{l}\text { - PLMS associated with severity of PD } \\
\text { symptom, sleep disturbance, and decreased } \\
\text { quality of life. }\end{array}$ \\
\hline $\begin{array}{l}\text { Obstructive } \\
\text { sleep apnea }\end{array}$ & $\begin{array}{l}\text { - OSA can mimic RBD symptoms, but no } \\
\text { evidence for increased rate of progression } \\
\text { to PD. } \\
\text { - No increased OSA in newly diagnosed PD. }\end{array}$ & $\begin{array}{l}\text { - Most studies did not show an association } \\
\text { between OSA and PD. } \\
\text { - A meta-analysis of } 5 \text { studies suggested } \\
\text { that PD patients have reduced risk for OSA. } \\
\text { - Other studies suggested that PD is more } \\
\text { common among individuals with insomnia. }\end{array}$ & $\begin{array}{l}\text { - Even coincidental OSA, if present, can still } \\
\text { be cause of somnolence and may warrant } \\
\text { treatment. }\end{array}$ \\
\hline $\begin{array}{l}\text { Excessive daytime } \\
\text { sleepiness and } \\
\text { sleep attacks }\end{array}$ & $\begin{array}{l}\text { - Contradictory results regarding the } \\
\text { involvement of EDS in prodromal PD. } \\
\text { - Case-control studies of newly diagnosed } \\
\text { PD demonstrated similar frequencies of EDS } \\
\text { in patients and controls. } \\
\text { - Other studies suggested that EDS may } \\
\text { precede PD. }\end{array}$ & $\begin{array}{l}\text { - EDS and sudden onset of sleep are } \\
\text { common in PD, in some studies more than } \\
50 \% \text { of patients. } \\
\text { - Frequency of EDS increases with disease } \\
\text { progression, severity of PD symptoms and } \\
\text { levodopa dosage. } \\
\text { - Increased hypocretin loss was observed } \\
\text { with advanced PD. }\end{array}$ & $\begin{array}{l}\text { - All dopaminergic agents can cause } \\
\text { somnolence. Some studies suggest that } \\
\text { dopamine agonist treatment may be } \\
\text { particularly associated with EDS in PD, } \\
\text { while others did not. } \\
\text { - Associated with dementia. }\end{array}$ \\
\hline Insomnia & $\begin{array}{l}\text { - Insomnia is not common in newly } \\
\text { diagnosed PD patients. } \\
\text { - Possible slight increase in insomnia in } \\
\text { prodromal PD. }\end{array}$ & $\begin{array}{l}\text { - Some studies suggested that the frequency } \\
\text { of insomnia increases with PD progression. } \\
\text { - Other studies demonstrated that the } \\
\text { frequency of insomnia remains stable } \\
\text { through follow-up, and may fluctuate } \\
\text { during the course of PD. }\end{array}$ & $\begin{array}{l}\text { - Insomnia is associated with depression in } \\
\text { PD, but significance of association is } \\
\text { unclear, since insomnia is often a } \\
\text { component of depression in general. }\end{array}$ \\
\hline $\begin{array}{l}\text { Circadian sleep-wake } \\
\text { cycle disruption }\end{array}$ & $\begin{array}{l}\text { - Analysis of newly diagnosed PD patients } \\
\text { suggested that disruption of the circadian } \\
\text { sleep-wake cycle may occur early in the } \\
\text { disease. It was not clear if this disruption } \\
\text { precedes the motor symptoms of PD. }\end{array}$ & $\begin{array}{l}\text { - Circadian melatonin levels had lower } \\
\text { amplitude in PD patients compared to } \\
\text { control. } \\
\text { - The lower melatonin levels were not } \\
\text { associated with disease duration, levodopa } \\
\text { doses and UPDRS scores. } \\
\text { - However a previous study suggested that } \\
\text { melatonin levels were affected by } \\
\text { dopaminergic treatment. }\end{array}$ & $\begin{array}{l}\text { - Hallucinations in PD are associated with } \\
\text { altered rest-activity rhythm. }\end{array}$ \\
\hline
\end{tabular}

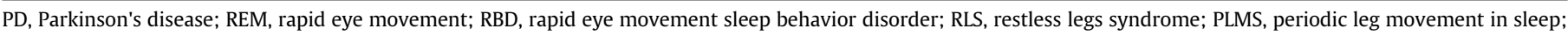
OSA, obstructive sleep apnea; EDS, excessive daytime sleepeiness; UPDRS, unified Parkinson's disease rating scale.

doses of L-dopa needed to control motor symptoms [46]. Post mortem studies of PD patients with and without RBD suggest that RBD is associated with more diffuse spread of $\alpha$-synuclein aggregation [47].

\section{Restless legs syndrome}

RLS is characterized by an unpleasant sensation in the lower limbs that typically occurs at rest in evening hours. This sensation is 


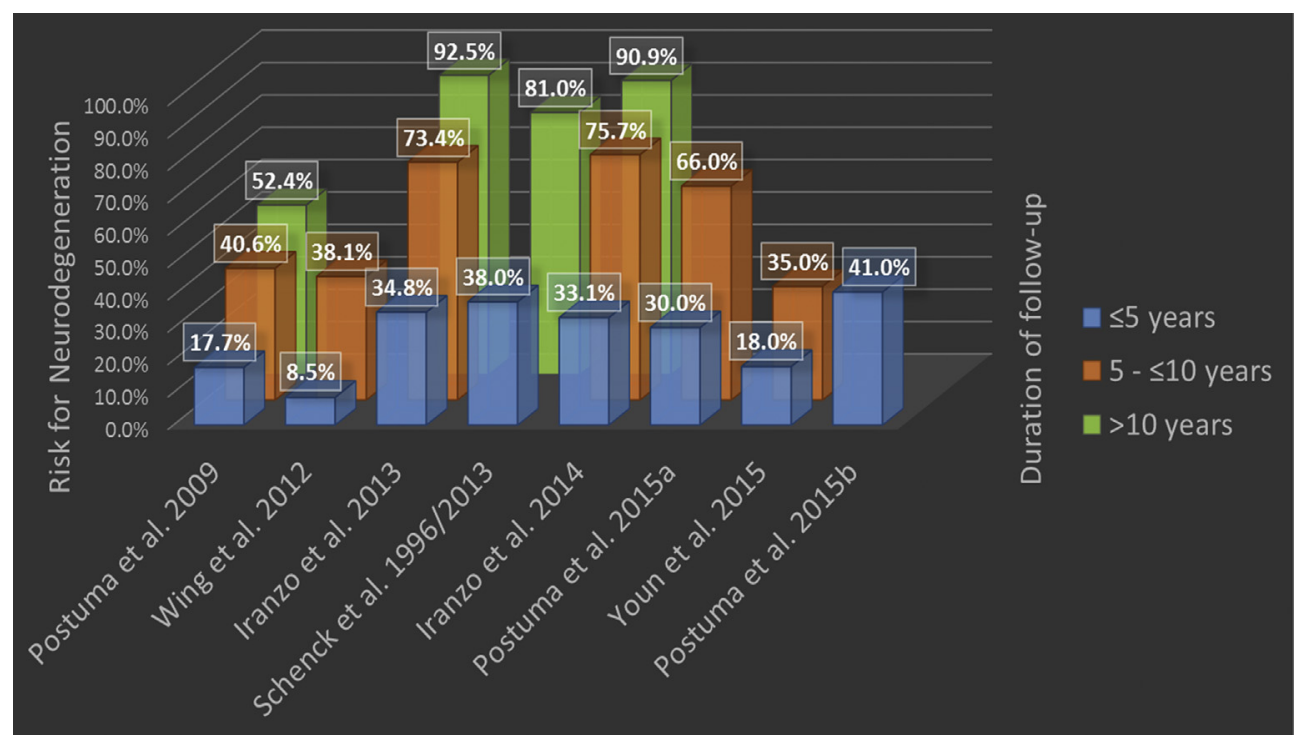

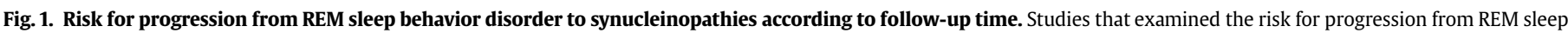

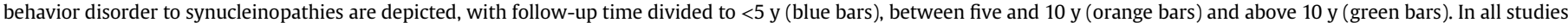

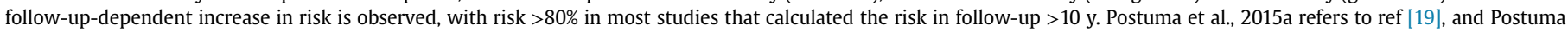
et al., 2015b refers to ref [36]. (For interpretation of the references to color in this figure legend, the reader is referred to the Web version of this article.)

relieved by movement of the legs, thus disturbing sleep initiation [48]. The association between RLS and PD is controversial; several studies suggested that RLS is more common among PD patients, while other studies demonstrated that the frequency or RLS among PD patients is similar to the general population [49]. Although dopaminergic treatment helps both conditions, pathological and imaging data do not support a pathophysiologic association. The pathological hallmarks of PD, $\alpha$-synuclein accumulation in Lewy bodies, were absent from post-mortem studies of patients with RLS [50]. Furthermore, iron levels in the SN are reduced in RLS and increased in PD [51]. It was demonstrated that using sonography in PD patients, it is possible to detect increased echogenicity of the substantia nigra, likely due to the cell loss. When comparing sonographic findings among patients with RLS and PD, increased echogenicity of the substantia nigra was observed only among PD patients [52]. Reduction in putamen uptake of [18 F]-dopa was observed in RLS patients, but it was not due to the loss of striatal neurons typical in PD [53]. Moreover, there was no clear decrease in [18 F]-dopa uptake and [123I]- $\beta$-CIT binding in RLS, while such decrease is also typical in PD [54,55].

\section{Periodic leg movement in sleep}

Patients with PLMS have repetitive, stereotypical lower limb movements during sleep, typically before the onset of REM sleep, and up to $80 \%$ RLS patients may suffer from PLMS as well [56]. As in RLS, patients with PLMS respond well to dopaminergic treatment. The prevalence of PLMS among PD patients in most reports is similar to controls [57], however the occurrence of PLMS in PD has been associated with PD severity [58] and with the degree of neurodegeneration [59]. In a study of PD patients with and without dopaminergic treatment, patients had slight and nonsignificant higher frequencies of PLMS than controls. Treated and non-treated PD patients had similar rates, but the groups were relatively small [60]. Treating PD with deep brain stimulation (DBS) could be associated with PLMS, potentially due to the reduced intake of dopaminergic treatment in patients who underwent DBS [61].

\section{Excessive daytime sleepiness}

EDS is a common complaint among patients with PD. Whether EDS is associated with prodromal PD is still controversial. Two reports suggested that elderly individuals with symptoms of EDS such as napping and feeling sleepy during the day, had higher PD risk $[17,18]$. Of note, in these studies EDS was not assessed by an objective method, and other common causes of EDS such as OSA were not ruled out. By contrast, other reports found that in de-novo PD cohorts, the rate of EDS was similar to the general population [62,63]; if not more common in clinical PD, it is hard to imagine how it could be a prodromal feature. As the course of PD progresses, EDS becomes more common, probably due to the involvement of multiple factors [64], including dopaminergic treatment, sedative drugs, neurodegeneration of regions of the reticular activating system that subserve wakefulness, and other co-morbidities that can occur in PD such as OSA, depression, and dementia [21]. Interestingly, it was demonstrated that hypocretin cells loss, which is typical in narcolepsy, may be common in PD [65], which may explain some of the narcolepsy-like sleep attacks that sometime occur during PD. These associations should be further studied in additional cohorts of PD patients.

Circadian sleep-wake cycle disruption in PD, often presenting as a combination of EDS and insomnia, may also be related to various factors that occur in, but not specific to, PD. Several PDrelated symptoms have circadian presentation, including motor activity, autonomic dysfunction, gastric function, hallucinations and others [66], which may suggest that circadian control is involved. Further supporting this possibility, it was observed that melatonin and cortisol regulation, which are involved in circadian regulation, can be disrupted in PD [67].

\section{Obstructive sleep apnea}

OSA is caused by partial or complete obstruction of the upper respiratory airways during sleep, leading to multiple episodes of apnea. OSA is associated with various conditions including obesity, neurological and neuromuscular disorders, facial dysmorphism and 
various environmental factors. There are contradictory results regarding the occurrence of OSA in PD. Several studies suggested that among PD patients the occurrence of OSA was similar to controls or even lower [21], which was also the conclusion of a meta-analysis of five studies [68], possibly due to reduced body mass index in PD. However, other studies reported that OSA may be more common in PD patients [69], or that PD is more common among individuals with insomnia [70]. Therefore the association between OSA and PD remains inconclusive.

\section{Insomnia}

Insomnia is the most prevalent sleep disorder, and is probably the most common sleep-related complaint in PD [71]. The classic pattern of insomnia in PD is sleep maintenance insomnia; patients fall asleep easily but waken early [72]. This may suggest a phaseadvanced dysregulated circadian rhythm. However, like most of the other sleep-related symptoms, insomnia is also multifactorial and non-specific for PD. Found in up to $80 \%$ of PD patients, it may be related to comorbid RLS, Circadian sleep-wake cycle disruption, depression, anxiety, dementia, etc. [21]. Insomnia is more prevalent in advanced and more severe PD, as the parkinsonian symptoms or adverse effects to anti-parkinsonian drugs can also contribute to disturbances in initiation or maintenance of sleep [73].

\section{Genetics of Parkinson disease - a brief overview}

Once considered a purely sporadic, environmental disease, PD is known today to have a strong genetic component. Estimates of the contribution of heredity to the risk for PD range between $27 \%$ and $60 \%$ in population and familial based studies $[74,75]$. So far, over 40 genetic loci and genes have been linked to PD and parkinsonism, including variants that are associated with mildly increased or decreased risk for PD, variants that are strong risk factors for PD, and mutations that necessarily cause PD [22,24]. Fig. 2 details the various genes that are known or suspected to be involved in sporadic $\mathrm{PD}$, autosomal dominant and autosomal recessive $\mathrm{PD}$, and in atypical forms of parkinsonism.

The most common PD-associated mutations are found in GBA and LRRK2. Different mutations in these genes have variable effects on risk for PD [76-79]. In some populations, including ArabBerbers and Ashkenazi Jews, the combined frequencies of variants in these genes may reach to $30-40 \%$ of all PD cases [80,81]. In other populations, including Japanese, Chinese, French-Canadian and Spanish, they account for $10-20 \%$ of PD patients, while in others they are found in less than $10 \%$ of PD patients [76,82,83]. GBA mutations can be divided to severe or mild mutations, and individuals with severe mutations have higher risk for PD and earlier age at onset than mild mutation carriers. As in sporadic PD, there are more men than women with GBA-associated PD [76]. Interestingly, it was demonstrated that the enzyme encoded by GBA, glucocerebrosidase, had reduced activity in brain and peripheral blood from PD patients with or without GBA mutations [84,85]. Different LRRK2 mutations, which were initially described in familial PD, also have a differential effect on the risk for PD. Some LRRK2 mutations, such as the p.G2019S, and the p.R1441C/G/H substitutions, confer higher risk for PD [82,86], while other substitutions such as p.G2385R among Asians are associated with only mildly increased risk for PD. Unlike sporadic and GBA-associated PD, the male:female ratio in LRRK2-associated PD is 1:1 [77].

Mutations and copy number variations in other genes are scarce and are probably responsible for less than $2 \%$ of all PD cases [22]. Mutations in only few genes are known to cause PD in an autosomal dominant manner, the first to be discovered are in SNCA [87],

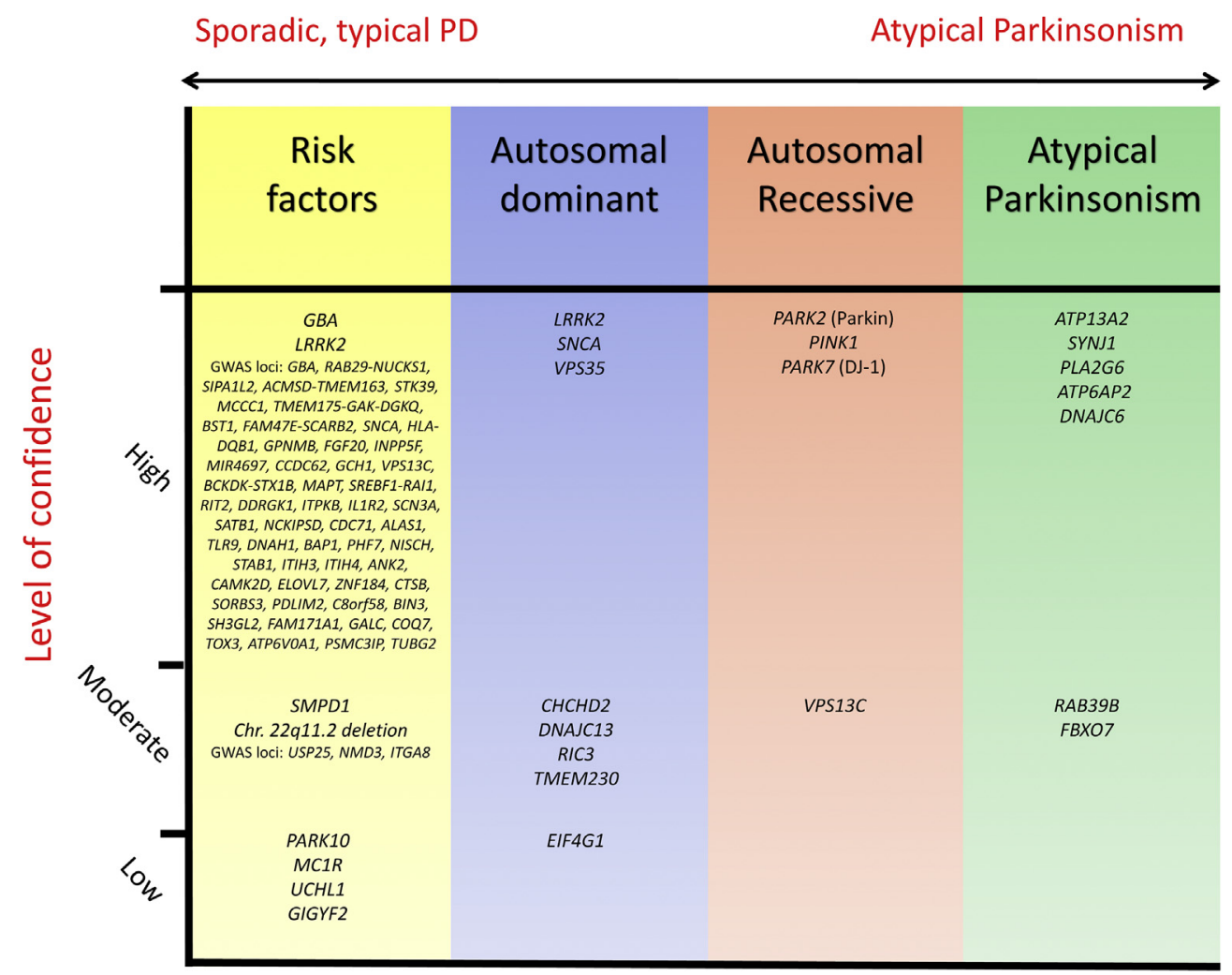

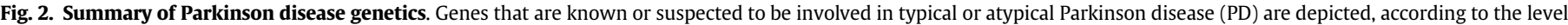

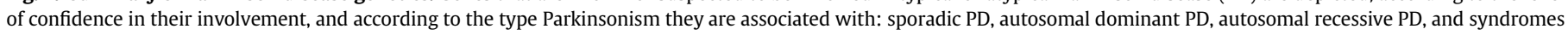
that include atypical parkinsonism. 
encoding $\alpha$-synuclein, the protein that accumulates in Lewy bodies. Point mutations, duplications and triplications of SNCA were described in autosomal dominant, mostly early-onset PD [88]. VPS35 mutations are the only other well-validated cause for autosomal dominant, typical PD, and they are very rare, probably accounting for less than $0.5 \%$ of PD patients [89]. While there is some compelling evidence that mutations in CHCHD2 [90], DNAJC13 [91], TMEM230 [92] and RIC3 [93] may also lead to autosomal dominant PD, more studies are necessary to fully accept these genes as PDcausing. In the cases of $\mathrm{CHCHD} 2$ and $\mathrm{GCH} 1$, only a few studies demonstrate this association, therefore additional case-control or familial studies are necessary to determine their role in PD. In the cases of DNAJC13 and TMEM230, the main evidence for association of these genes with PD comes from the same large family, therefore additional case-control and familial studies are necessary to determine which of them is associated with PD, if at all. Heterozygous carriage of specific SMPD1 mutations were also suggested to strongly increase the risk for PD [94,95], but more case-control and familial studies in additional populations, as well as functional studies on its potential mechanism, are needed to demonstrate the association between SMPD1 and PD, and to better understand the role of SMPD1 in PD.

The most common cause of autosomal recessive PD are mutations in PARK2 (Parkin), leading to early-onset, often juvenile PD, which account for $8.6 \%$ of PD with age at onset $<50$ y [96]. Homozygous and compound heterozygous mutations in PINK1 and PARK7 (DJ1) are other well validated causes of autosomal recessive, early onset PD or PD-like disease [96]. Heterozygous mutations in PARK2 [97], PINK1 [98] and PARK7 [99] may be risk factors for typical, late or early onset disease, but this needs to be confirmed in additional studies. Other genes that are often cited as autosomal recessive $\mathrm{PD}$-causing genes are in fact leading to atypical forms of parkinsonism (Fig. 1) and their role in typical PD is still not clear.

A recent PD GWAS included data from a total of 19,061 PD patients and 100,833 controls, and identified 24 loci that likely increase or decrease the risk for PD, and a more recent GWAS with a total of $>25,000$ patients and $>400,000$ controls identified 17 additional loci (Fig. 2) [23,24]. These loci include genes that were already associated with familial and sporadic PD such as GBA, LRRK2, SNCA, and GCH1 (although rare GCH1 mutations in sporadic PD were reported in only one study [100], which requires replications in additional case-control studies of sporadic PD), and genes with mutations that had not yet been described in PD. Recently, mutations in VPS13C, one of the genes implicated in the GWAS, were identified in autosomal recessive, severe and rapidly progressive parkinsonism [101]. The loci of other genes that cause typical or atypical parkinsonism, including PARK2, PINK1, PARK7 and $A T P 13 A 2$ [22], were not identified in the GWAS meta-analysis $[23,24]$. It is important to note that although the calculated effects on PD risk associated with these GWAS markers are small, with odds ratios (OR) typically ranging between 0.75 and 1.80 $[23,24]$, each loci can harbor genetic variants with either minor, medium, or major effect of the risk for PD.

\section{Genetic overlap between RBD and PD}

Although the association between RBD and PD was initially reported 2 decades ago, only recently genetic studies that specifically focus on RBD have been performed. The strongest genetic association reported thus far, is with mutations in GBA [32,102]. Clinically, GBA-associated PD and RBD-associated PD have many similarities. Both $G B A$ and RBD are associated with rapid motor progression $[103,104]$ and the postural-instability-gait-dysfunction phenotype [105,106], autonomic dysfunction [45,103], cognitive decline and faster progression to dementia $[43,103,107]$. Moreover, both GBA and RBD are associated with DLB [15,37,108] and MSA [37,109]. Therefore, it is no surprise to find that GBA mutations were associated with RBD in cohorts of idiopathic RBD patients [32,102]. Moreover, this association was even stronger than the association with PD in a similar population [110], suggesting that GBA mutations are more specifically associated with the RBD subtype of PD. Furthermore, in clinical PD patients screened with an RBD questionnaire, GBA mutations were associated with probable RBD [32]. It was further demonstrated that among biallelic GBA mutation carriers, as well as among heterozygous carriers who did not have PD, RBD scores were significantly worse than controls [111]. From a pathological point of view, both RBD-associated PD and GBAassociated PD probably have a more diffused spread of $\alpha$-synuclein accumulation $[47,112]$. These are suggestive leads, but more studies are needed to confirm the association between GBA and RBD.

While GBA- and RBD-associated PD are clinically similar, LRRK2associated PD typically has a more benign course, with less rapid cognitive decline [113], less hyposmia (reduced sense of smell) and less autonomic dysfunction than sporadic PD [114]. Therefore, it was not surprising that LRRK2 mutations were not associated with idiopathic RBD [30] nor with probable RBD in a clinical PD cohort [115]. In two studies that examined PD patients and controls with LRRK2 mutations, RBD was less common in LRRK2 mutation carriers [116,117]. Our unpublished data confirms the lack of association between LRRK2 and RBD (Gan-Or et al., unpublished data). The differences between male:female ratios in LRRK2-associated PD, in which there is equal (1:1) ratio [77], and RBD, in which male gender strongly predominates [118], provide further support for the lack of association between LRRK2 mutations and RBD.

In an initial screening of nine loci that were previously associated with PD, an association between markers at the SCARB2 and $M A P T$ loci as found in idiopathic RBD patients, and additional markers at the GAK and SNCA loci demonstrated a marginal association [31]. An additional study, in a smaller population, also suggested that MAPT may be associated with RBD [119]. However, this association need to be confirmed in larger studies. The association with SCARB2 is of special interest to the RBD/GBA association, since this gene encodes the transporter responsible for glucocerebrosidase transport, from the endoplasmic reticulum and the lysosome [120]. Recently, it was demonstrated that the DLBassociated gene, APOE, is not associated with RBD [121]. However, larger scale GWASs is needed to examine whether other PDassociated loci are specifically associated with RBD or whether RBD might have unique genetic risk factors that were not detected in unselected PD GWASs. Whether RBD is associated with other genes that cause familial PD remains undetermined, however various studies reported RBD in patients with mutations in SNCA [122] and PARK2 [123].

Hexanucleotide expansions of C9orf72, which causes amyotrophic lateral sclerosis and fronto-temporal dementia, have a minor or no role in PD [124]. However, one report identified two C9orf72 expansion carriers in two RBD patients [125]. To determine this was a random finding or whether a true association exists, studies in additional populations are necessary. Another gene that was suggested to be involved in $\mathrm{PD}$, but was later refuted, is the melanoma-associated gene MC1R [126,127]. It was recently shown that variants in this gene are also not associated with RBD [128].

Overall, it seems that the genetic background of RBD and PD overlap considerably, but not fully, suggesting that RBD-associated PD has its own genetic background. It is possible that some markers seen in GWASs of PD are particularly markers of RBD-associated PD that become significant due to the high frequency of RBD in PD cohorts. If so, selecting specifically RBD patients (or patients with other markers of disease subtype) may increase the power of GWAS to find important associations. To map the genetic risk loci in RBD, 
two approaches can be taken: 1) performing GWAS on RBD cohorts and 2) re-analyzing data from the PD GWASs only in PD patients who also have RBD.

Preliminary data suggested that some genetic factors may affect the rate of progression from RBD to the defined synucleinopathy diseases [31]. This issue should be studied in larger cohorts, since it may have important implications for future clinical trials. If genetic factors can predict the rate of progression from RBD to synucleinopathies, RBD patients who carry specific variants that are associated with more rapid progression could be prioritized for clinical trials of drugs that aim to stop the progression of the disease.

\section{Restless legs syndrome, periodic leg movements during sleep and Parkinson disease genetics}

The largest published RLS GWAS included 922 cases and 1526 controls in the discovery phase and 3935 cases and 5754 controls in the replication phase [25]. While this is not as large as the PD GWASs [24], it is large enough to provide reliable results. Thus far, six genes and genetic loci were associated with RLS in GWASs: MEIS1, BTBD9, PTPRD, MAP2K5/SKOR1, TOX3 and the intergenic rs6747972 on chromosome 2 [25]. Given the strong clinical overlap between RLS and PLMS, it is not surprising that five of the GWAS loci associated with RLS, were also associated with PLMS [129]. None of these loci were associated with PD, and none of the 24 PD GWAS loci were associated with RLS [24]. When examining the online database PDgene (www.pdgene.org), which provides metaanalyzed results from various GWASs, five of the six RLS markers, rs2300478 (MEIS1), rs9357271 (BTBD9), rs1975197 (PTPRD), rs12593813 (MAP2K5/SKOR1) and rs6747972 (intergenic), have a meta-analysis $p$-value $>0.05$, demonstrating that these markers are not associated with PD. However, one RLS marker in the TOX3 locus, rs3104767, had an OR of 1.07 (95\% confidence interval [CI] $1.04-1.10, p=5.03 \times 10^{-5}$ ) in a meta-analysis of 15 PD studies (PDgene). In the largest RLS GWAS it had an OR of $1.35,95 \% \mathrm{CI}$ $1.27-1.43, p=9.40 \times 10^{-19}$ [25]. Of note, this marker is not significant in the PD GWAS meta-analysis after correction for multiple comparisons, so it requires further study. Two studies specifically examined the RLS GWAS markers in PD case-control cohorts, and no evidence for association with PD was found [26,29].

Several studies of familial RLS have found genetic loci that may be involved in autosomal dominant or recessive RLS. Table 2 details these loci as well as those identified in the RLS GWAS. Some of these familial loci, which received the aliases of RLS1 - RLS8 (OMIM.org), include genes that were implicated in RLS GWAS (RLS3 includes PTPRD, RLS6 includes BTBD9, and RLS7 includes MEIS1), while the other loci were not associated with a specific gene. It remains undetermined whether these loci indeed represent true genetic determinants of RLS, since most were replicated a few times at most, or not at all [130]. When comparing these loci to known PD loci, there is very little evidence for any potential overlap between these RLS loci and PD loci and known genes. The PD-associated gene LRRK2 is found within the RLS1 locus, however this locus includes more than half of the long arm of chromosome 12 (OMIM.org), which contains a few hundred genes. RLS2, RLS3, RLS4, RLS5, RLS7 and RLS8 do not include PD-associated genes. RLS6 contains the HLA genes, some of which were associated PD [24], but it also includes BTBD9 [131]. Additional candidate gene studies in RLS suggested the involvement of $M A O A$ [132] and NOS1 [133], and while these genes are awaiting replication studies, they are also not associated with PD (PDgene) [24].

Other studies specifically examined PD-associated genes or genetic markers in RLS. There was no association between one of the strongest risk factors for PD, the MAPT associated SNP rs1052553, and RLS in a case-control study [28]. Studies of families that

Table 2

Genetic loci and genes associated with restless legs syndrome.

\begin{tabular}{|c|c|c|c|}
\hline $\begin{array}{l}\text { Locus name } \\
\text { (OMIM) }\end{array}$ & $\begin{array}{l}\text { Chromosomal } \\
\text { region }\end{array}$ & Implicated genes & Comments \\
\hline \multicolumn{4}{|c|}{ RLS OMIM loci } \\
\hline RLS1 & $12 q 12-q 21$ & Yet to be identified. & $\begin{array}{l}\text { Large locus that includes more than half of the large arm of chromosome } 12 \text {. The PD-associated gene } L R R K 2 \\
\text { is in this locus, but there is no evidence that it has a role in RLS. }\end{array}$ \\
\hline RLS2 & 14q13-q21 & Yet to be identified. & $\begin{array}{l}\text { This locus represents about one quarter of the long arm of chromosome } 14 \text {, and it includes dozens of genes, } \\
\text { none of which was associated with PD. }\end{array}$ \\
\hline RLS3 & $9 \mathrm{p} 24-\mathrm{p} 22$ & PTPRD & $\begin{array}{l}\text { This locus encompasses about half of the short arm of chromosome } 9 \text {, and it includes the PTPRD gene, which } \\
\text { is a well validated GWAS marker. There is no evidence that in the families in which this locus was identified } \\
\text { there are mutations in PTPRD that can explain the association. }\end{array}$ \\
\hline RLS4 & $2 q 33$ & Yet to be identified. & This locus includes dozens of genes, none of which was specifically associated with RLS \\
\hline RLS5 & 20p13 & Yet to be identified. & $\begin{array}{l}\text { This locus represents about a fifth of the short arm of chromosome } 20 \text {, and includes dozens of genes, none of } \\
\text { which was specifically associated with RLS. }\end{array}$ \\
\hline RLS6 & $6 \mathrm{p} 21$ & BTBD9 & $\begin{array}{l}\text { This locus was identified in a genome wide association study, with variants around the BTBD9 gene. This } \\
\text { region contains the HLA genes that may be involved in PD. However, since it is very likely that BTBD9 is } \\
\text { responsible for RLS in this region, there is no suggested genetic pleiotropy in this locus between RLS and PD. }\end{array}$ \\
\hline RLS7 & 2p14-p13 & MEIS1 & $\begin{array}{l}\text { This locus is was identified in case-control studies and GWAS, and includes the strongest genetic risk factor } \\
\text { for RLS detected to date. }\end{array}$ \\
\hline RLS8 & $5 q 31$ & $\begin{array}{l}\text { PCDHA3, WWC2, } \\
\text { ATRN, FAT2 }\end{array}$ & $\begin{array}{l}\text { While the most plausible candidate in this region was reported to be } P C D H A 3 \text {, it is still possible that any of } \\
\text { the other genes is associated with RLS in this locus, and additional studies are required to determine the } \\
\text { association of this locus with RLS. }\end{array}$ \\
\hline \multicolumn{4}{|c|}{ Genome-wide association study loci } \\
\hline NA & Chromosome 2 & MEIS1 & $\begin{array}{l}\text { The GWAS associated marker was rs } 2300478 \text {, and the minor allele was associated with an increased risk for } \\
\text { RLS (OR 1.68). Also called RLS7. }\end{array}$ \\
\hline NA & Chromosome 2 & Intergenic region & $\begin{array}{l}\text { The GWAS associated marker was rs6747972, and the minor allele was associated with an increased risk for } \\
\text { RLS (OR 1.23). }\end{array}$ \\
\hline NA & Chromosome 6 & BTBD9 & $\begin{array}{l}\text { The GWAS associated marker was rs9357271, and the major allele was associated with an increased risk for } \\
\text { RLS (OR 1.47). Also called RLS6. }\end{array}$ \\
\hline NA & Chromosome 9 & PTPRD & $\begin{array}{l}\text { The GWAS associated marker was rs } 1975197 \text {, and the minor allele was associated with an increased risk for } \\
\text { RLS (OR 1.29). Found in the RLS3 locus. }\end{array}$ \\
\hline NA & Chromosome 15 & MAP2K5, SKOR1 & $\begin{array}{l}\text { The GWAS associated marker was rs12593813, and the major allele was associated with an increased risk for } \\
\text { RLS (OR 1.41). }\end{array}$ \\
\hline NA & Chromosome 16 & TOX3 & $\begin{array}{l}\text { The GWAS associated marker was rs } 3104767 \text {, and the major allele was associated with an increased risk for } \\
\text { RLS (OR 1.35). }\end{array}$ \\
\hline
\end{tabular}


presented both with PD and RLS also provided no evidence for genetic overlap between PD and RLS. PARK2 mutations did not segregate with RLS and did not affect the phenotype of RLS in two families with PARK2-associated PD [134]. The Rep1 allele of SNCA which is more frequent in PD than controls, was in fact less frequent in RLS, demonstrating opposite directionality of effect in PD and RLS [27]. Therefore, there appears to be no evidence of a true overlap between PD- and RLS-associated genes and genetic loci.

\section{Obstructive sleep apnea genetics and Parkinson disease}

Studying the genetics of OSA is complicated by comorbidities that can predispose to OSA and are also heritable. These comorbidities can be divided into four major groups: 1) obesity and metabolic disturbances, 2) craniofacial and upper airway morphology, 3) ventilation control, and 4) sleep and circadian rhythm control. It is also likely that other genes unrelated to these conditions may also be risk factors for OSA. For example, family studies that demonstrated that first-degree relatives of OSA patients were more likely to have OSA after adjusting for body mass index [135].

OSA is a common condition often with familial aggregation, and although there are still not enough genetic studies, in recent years more progress has been made. Various candidate gene studies have highlighted genes including LPAR1, PLEK, PTGER3 [136], TNF [137], CRP [138], GDNF [139], HTR2A [140], PPARGC1B [141], NRG1 [142], FTO [143], TRABD2B [144], SLC6A4 [145] and LEPR [146], most of which have not been replicated; therefore at this point they should be considered with caution. Possible exceptions are TNF, LEPR and HTR2A, which has some evidence for association with OSA in more than one study. A meta-analysis demonstrated an association between a variant in the promoter of TNF and risk for OSA [137], and another meta-analysis suggested that variants in LEPR are associated with a reduced risk for OSA [146]. Interestingly, it was demonstrated that a TNF polymorphism was associated with increased TNF- $\alpha$ levels in children with OSA, and significant increase in excessive daytime sleepiness symptoms was observed in association with this polymorphism [147]. Therefore, the association with TNF may be explained by increased sleepiness which makes them more likely to present. Meta-analysis of HTR2A variants suggested association with OSA only in men [140]. However, none of these genes were replicated in a recent, large GWAS metaanalysis that included a total of 12,558 participants of Hispanic origin [144]. Another GWAS-level significant locus for OSA was suggested in this study, around the GPR83 gene [144]. However, this study did not include a replication population, and these associations should be considered with caution. None of these genes or genetic loci were implicated in PD (PDgene) [24], suggesting that the genetic background of the two conditions is probably distinct. However, since more genetic studies are necessary in OSA, it cannot be determined with certainty that there is no true genetic overlap.

\section{Circadian sleep-wake cycle disruption genetics and Parkinson disease}

Many of the genes and proteins regulating the circadian clock are well characterize, including PER1, PER2, PER3, CRY1, CRY2, CLOCK, ARNTL, ARNTL2, CSNK1D, CSNK1E, TIMELESS, NPAS2, NR1D1, DBP, FBXL3, BHLHE40, BHLHE41 and others that were thoroughly reviewed [148-150]. It important to note that most of the knowledge on the function of these genes and proteins is derived from animal studies [151], therefore the role of human genetic variations in these genes and their potential effects on sleep patterns require more study. However, variants in some of these genes were suggested to be involved in circadian clock patterns or related disorders. However, often they were not replicated in additional studies, and none of these genes and variants were also associated with risk for PD [24]. For example, one of the most studied genetic variants is a SNP in the CLOCK $3^{\prime}$ untranslated region, which was associated with diurnal preference [152], but this association was not replicated [153]. This variant was also suggested to be involved in sleep regulation in various psychiatric disorders, but also with inconsistent results [154,155]. Like all variants in the CLOCK locus, this variant is not associated with PD in the meta-analysis of PD GWASs (PDgene) [24]. Similarly, other variants in these genes that were suggested to have effects on the circadian cycle or sleep-related measures, such as PER1 rs2735611 [156], PER2 rs2304672, PER3 rs228697 and ARTNL2 rs922270 [157], are also not associated with PD in this meta-analysis ( $p>0.05$ for all SNPs). Similar observations, i.e., possible association with circadian sleep cycle and lack of association with PD, are true for other variants in these genes [158,159]. Since some variants in these genes may also be associated with affective disorders, their potential effect on common psychiatric symptoms in PD such as depression and anxiety should be further studied.

Recently, three large GWASs examined the association of genetic markers with chronotype, with substantial genetic overlap. A total of nine genes (RGS16, PER2, FBXL13, AK5, HCRTR2, HTR6, TNRC6B, $A P H 1 A$ and $E R C 2)$ were identified in two or three of the studies, thus well validated [160-162]. As the other genes associated with the circadian sleep-wake cycle, these two are not associated with PD.

\section{Genetics of insomnia and excessive daytime sleepiness}

Genetic studies of both insomnia and EDS are complicated by the various factors that are associated with these two conditions. Therefore, identifying genes and variants specifically associated with insomnia and EDS is challenging, which may explain the relatively low number of genetic studies of these conditions [163]. Since EDS can be related to circadian sleep-wake cycle disruption, PLMS and other sleep disorders that were reviewed here, the same genes involved in these disorders can also be involved in EDS [164]. Several twin studies suggested that heritability is indeed a contributing factor for insomnia [165,166], but most of these studies did not control for the heritability of comorbidities that may cause secondary insomnia. Two GWASs $(167,168)$ and several candidate gene case-control studies were performed in attempt to identify genetic markers of insomnia. While several candidate genes were suggested, including ROR1, PLCB1 [167], CACNA1C [168], CLOCK [169], SLC6A4 [170] and GABRB3 [171], they are still awaiting proper replication studies in order to determine their role in insomnia. None of these genes was previously associated with PD.

\section{Conclusions}

Generally, the genetic study of sleep-related disorders still lags behind other medical fields, although in recent years some progress has been made. Only a few GWASs have been performed in sleep disorders, and while basic genetic twin and familial studies had been performed in the past, there are very few studies that applied next generation sequencing technologies on families with sleeprelated disorders. So far, there is no evidence for overlap in genetic predisposition for PD and either insomnia, EDS, OSA or circadian sleep-wake cycle disruption. In addition, there is no known overlap between RLS/PLMS genetic markers and PD, although this should be further studied.

In contrast, there is convincing evidence that the genetic basis of PD and RBD overlap, at least partially. Since we now know that the vast majority of cases of RBD have in fact a synucleinopathy in progress, this is not surprising. Of note, although not surprising, these observations linking some PD genetic markers and RBD may have importance for future studies and clinical trials. For instance, 
when asymptomatic carriers of GBA mutations are being followed up, screening for RBD should be considered for early detection of conversion to a synucleinopathy. Such population of GBA mutation carriers with RBD could be ideal for future clinical trials, since they are highly likely to convert to PD or another synucleinopathy. More genetic studies on RBD are required to identify additional genetic factors that are either shared with PD or unique to RBD, which will allow better characterization of this population.

\section{Practice points}

1) Little is known about the genetics of most sleep-related disorders, especially those with multiple comorbidities such as insomnia, EDS and OSA. Identification of genetic markers that specifically affect these disorders is challenging, and adjusting for factors that affect the predisposition for these disorders (for example, controlling for $\mathrm{BMI}$ in genetic studies of OSA) is necessary in order to identify such genetic markers.

2) While sleep-related disturbances are probably the most common non-motor symptoms in PD, the genetic evidence, as well as most of the clinical, imaging and pathological evidence suggest that only RBD is specifically associated with PD. Although it is possible that RLS and EDS occur more in PD, it is most likely not due to shared genetic predisposition.

3) RBD is manifesting as a sleep disorder, but in most cases it is in fact a neurodegenerative synucleinopathy in early stages, and should be considered as such by sleep specialists.

\section{Research agenda}

1) More genetic studies are needed in sleep-related disorders, whether candidate-gene or GWAS approaches in case-control cohorts, or studies of familial cases with next generation sequencing. Large collaborations will be needed to overcome the difficulties arising from the multiple comorbidities involved in most of these disorders.

2) Although the current genetic evidence support lack of pleiotropy between RLS and PD, more studies are needed, specifically of the TOX3 locus but also others, to conclusively elucidate this possibility.

3) To better understand the progression from RBD to the different synucleinopathies, large and preferably prospective genetic studies that examine how genetic variants are associated with RBD progression are needed. Such studies should examine both the rate of progression, and to which synucleinopathy RBD progresses into, and if there are genetic markers that are specific to RBD and were not detected in PD studies.

4) Future clinical trials focusing on RBD patients should be among the leading strategies to identify drugs for PD. Such studies can be stratified by the genetic status of the patients. For example, studying drugs that aim to modify the enzymatic activity of the enzyme encoded by GBA would ideally be performed on RBD patients with $\overline{\mathrm{GBA}}$ mutations.

\section{Conflicts of interest}

ZGO received consultation and travel fees from Sanofi-Genzyme and Lesosomal Therapeutics Inc. (LTI). RNA received consultation and travel fees from Sanofi-Genzyme and Prophase, GAR reports no conflict of interests, RBP received funding for consultancy from Biotie, Roche, Biogen, and speaker fees from Teva and Novartis.

\section{Acknowledgements}

We thank Jay Ross for reading the manuscript and providing useful comments. ZGO is supported by a postdoctoral fellowship from the Canadian Institutes for Health Research (CIHR) and received grants from the Michal J. Fox Foundation for Parkinson's research. GAR holds a Canada Research Chair in Genetics of the Nervous System and the Wilder Penfield Chair in Neurosciences. RBP received grants from the Fonds de la Recherche en Sante Quebec, CIHR, Parkinson Society Canada, the Weston-Garfield Foundation, and the Webster Foundation.

\section{References}

[1] Kowal SL, Dall TM, Chakrabarti R, Storm MV, Jain A. The current and projected economic burden of Parkinson's disease in the United States. Mov Disord 2013;28(3):311-8.

[2] de Lau LM, Breteler MM. Epidemiology of Parkinson's disease. Lancet Neurol 2006;5(6):525-35.

[3] de Rijk MC, Breteler MM, Graveland GA, Ott A, Grobbee DE, van der Meche FG, et al. Prevalence of Parkinson's disease in the elderly: the Rotterdam study. Neurology 1995;45(12):2143-6.

[4] de Rijk MC, Launer LJ, Berger K, Breteler MM, Dartigues JF, Baldereschi M, et al. Prevalence of Parkinson's disease in Europe: a collaborative study of population-based cohorts. Neurologic diseases in the elderly research group. Neurology 2000;54(11 Suppl. 5):S21-3.

[5] Dorsey ER, Constantinescu R, Thompson JP, Biglan KM, Holloway RG, Kieburtz K, et al. Projected number of people with Parkinson disease in the most populous nations, 2005 through 2030. Neurology 2007;68(5):384-6.

[6] Lees AJ, Hardy J, Revesz T. Parkinson's disease. Lancet 2009;373(9680): 2055-66.

[7] Angot E, Steiner JA, Hansen C, Li JY, Brundin P. Are synucleinopathies prion-like disorders? Lancet Neurol 2010;9(11):1128-38.

[8] Berg D, Postuma RB, Bloem B, Chan P, Dubois B, Gasser T, et al. Time to redefine PD? Introductory statement of the MDS Task Force on the definition of Parkinson's disease. Mov Disord 2014;29(4):454-62.

[9] Fearnley JM, Lees AJ. Ageing and Parkinson's disease: substantia nigra regional selectivity. Brain 1991;114(Pt 5):2283-301.

[10] Fabbrini G, Barbanti P, Aurilia C, Vanacore N, Pauletti C, Meco G. Excessive daytime sleepiness in de novo and treated Parkinson's disease. Mov Disord 2002;17(5):1026-30.

[11] Gjerstad MD, Aarsland D, Larsen JP. Development of daytime somnolence over time in Parkinson's disease. Neurology 2002;58(10):1544-6.

[12] Iranzo A, Santamaria J, Rye DB, Valldeoriola F, Marti MJ, Munoz E, et al. Characteristics of idiopathic REM sleep behavior disorder and that associated with MSA and PD. Neurology 2005;65(2):247-52.

[13] Postuma RB, Lang AE, Massicotte-Marquez J, Montplaisir J. Potential early markers of Parkinson disease in idiopathic REM sleep behavior disorder. Neurology 2006;66(6):845-51.

*[14] Schenck CH, Bundlie SR, Mahowald MW. Delayed emergence of a parkinsonian disorder in 38\% of 29 older men initially diagnosed with idiopathic rapid eye movement sleep behaviour disorder. Neurology 1996;46(2):388-93.

*[15] Iranzo A, Molinuevo JL, Santamaria J, Serradell M, Marti MJ, Valldeoriola F, et al. Rapid-eye-movement sleep behaviour disorder as an early marker for a neurodegenerative disorder: a descriptive study. Lancet Neurol 2006;5(7):572-7.

[16] Wong JC, Li Y, Schwarzschild MA, Ascherio A, Gao X. Restless legs syndrome: an early clinical feature of Parkinson disease in men. Sleep 2014;37(2):369-72.

[17] Abbott RD, Ross GW, White LR, Tanner CM, Masaki KH, Nelson JS, et al. Excessive daytime sleepiness and subsequent development of Parkinson disease. Neurology 2005;65(9):1442-6.

[18] Gao J, Huang X, Park Y, Hollenbeck A, Blair A, Schatzkin A, et al. Daytime napping, nighttime sleeping, and Parkinson disease. Am J Epidemiol 2011;173(9):1032-8.

\footnotetext{
* The most important references are denoted by an asterisk.
} 
*[19] Postuma RB, Gagnon JF, Bertrand JA, Genier Marchand D, Montplaisir JY. Parkinson risk in idiopathic REM sleep behavior disorder: preparing for neuroprotective trials. Neurology 2015;84(11):1104-13.

[20] Trenkwalder C, Allen R, Hogl B, Paulus W, Winkelmann J. Restless legs syndrome associated with major diseases: a systematic review and new concept. Neurology 2016;86(14):1336-43.

[21] Iranzo A. Sleep in neurodegenerative diseases. Sleep Med Clin 2016;11(1): $1-18$.

*[22] Gan-Or Z, Dion PA, Rouleau GA. Genetic perspective on the role of the autophagy-lysosome pathway in Parkinson disease. Autophagy 2015;11 (9): $1443-57$.

*[23] Chang D, Nalls MA, Hallgrimsdottir IB, Hunkapiller J, van der Brug M, Cai F, et al. A meta-analysis of genome-wide association studies identifies 17 new Parkinson's disease risk loci. Nat Genet 2017;49(10):1511-6.

*[24] Nalls MA, Pankratz N, Lill CM, Do CB, Hernandez DG, Saad M, et al. Largescale meta-analysis of genome-wide association data identifies six new risk loci for Parkinson's disease. Nat Genet 2014;46(9):989-93.

*[25] Winkelmann J, Czamara D, Schormair B, Knauf F, Schulte EC, Trenkwalder C, et al. Genome-wide association study identifies novel restless legs syndrome susceptibility loci on 2p14 and 16q12.1. PLoS Genet 2011;7(7), e1002171.

[26] Gan-Or Z, Alcalay RN, Bar-Shira A, Leblond CS, Postuma RB, Ben-Shachar S, et al. Genetic markers of restless legs syndrome in Parkinson disease. Parkinsonism Relat Disord 2015;21(6):582-5.

[27] Lahut S, Vadasz D, Depboylu C, Ries V, Krenzer M, Stiasny-Kolster K, et al. The PD-associated alpha-synuclein promoter Rep1 allele 2 shows diminished frequency in restless legs syndrome. Neurogenetics 2014;15(3): 189-92.

[28] Roco A, Jimenez-Jimenez FJ, Alonso-Navarro H, Martinez C, Zurdo M, Turpin-Fenoll L, et al. MAPT1 gene rs1052553 variant is unrelated with the risk for restless legs syndrome. J Neural Transm (Vienna) 2013;120(3): 463-7.

[29] Vilarino-Guell C, Soto AI, Young JE, Lin SC, Uitti RJ, Wszolek ZK, et al. Susceptibility genes for restless legs syndrome are not associated with Parkinson disease. Neurology 2008;71(3):222-3.

[30] Fernandez-Santiago R, Iranzo A, Gaig C, Serradell M, Fernandez M, Tolosa E, et al. Absence of LRRK2 mutations in a cohort of patients with idiopathic REM sleep behavior disorder. Neurology 2016;86(11):1072-3.

[31] Gan-Or Z, Girard SL, Noreau A, Leblond CS, Gagnon JF, Arnulf I, et al. Parkinson's disease genetic loci in rapid eye movement sleep behavior disorder. J Mol Neurosci 2015;56(3):617-22.

[32] Gan-Or Z, Mirelman A, Postuma RB, Arnulf I, Bar-Shira A, Dauvilliers Y, et al. GBA mutations are associated with rapid eye movement sleep behavior disorder. Ann Clin Transl Neurol 2015;2(9):941-5.

[33] Postuma RB, Aarsland D, Barone P, Burn DJ, Hawkes CH, Oertel W, et al. Identifying prodromal Parkinson's disease: pre-motor disorders in Parkinson's disease. Mov Disord 2012;27(5):617-26.

[34] Iranzo A, Stockner H, Serradell M, Seppi K, Valldeoriola F, Frauscher B, et al. Five-year follow-up of substantia nigra echogenicity in idiopathic REM sleep behavior disorder. Mov Disord 2014;29(14):1774-80.

[35] Wing YK, Li SX, Mok V, Lam SP, Tsoh J, Chan A, et al. Prospective outcome of rapid eye movement sleep behaviour disorder: psychiatric disorders as a potential early marker of Parkinson's disease. J Neurol Neurosurg Psychiatry 2012;83(4):470-2.

[36] Youn S, Kim T, Yoon IY, Jeong J, Kim HY, Han JW, et al. Progression of cognitive impairments in idiopathic REM sleep behaviour disorder. J Neurol Neurosurg Psychiatry 2016 Aug;87(8):890-6.

[37] Postuma RB, Iranzo A, Hogl B, Arnulf I, Ferini-Strambi L, Manni R, et al. Risk factors for neurodegeneration in idiopathic rapid eye movement sleep behavior disorder: a multicenter study. Ann Neurol 2015;77(5): 830-9.

[38] Iranzo A, Tolosa E, Gelpi E, Molinuevo JL, Valldeoriola F, Serradell M, et al. Neurodegenerative disease status and post-mortem pathology in idiopathic rapid-eye-movement sleep behaviour disorder: an observational cohort study. Lancet Neurol 2013;12(5):443-53.

[39] Kang SH, Yoon IY, Lee SD, Han JW, Kim TH, Kim KW. REM sleep behavior disorder in the Korean elderly population: prevalence and clinical characteristics. Sleep 2013;36(8):1147-52.

[40] Ohayon MM, Caulet M, Priest RG. Violent behavior during sleep. J Clin Psychiatry 1997;58(8):369-76. quiz 77.

*[41] Gagnon JF, Postuma RB, Mazza S, Doyon J, Montplaisir J. Rapid-eyemovement sleep behaviour disorder and neurodegenerative diseases. Lancet Neurol 2006;5(5):424-32.

[42] Simuni T, Sethi K. Nonmotor manifestations of Parkinson's disease. Ann Neurol 2008;64(Suppl. 2):S65-80.

[43] Anang JB, Gagnon JF, Bertrand JA, Romenets SR, Latreille V, Panisset M, et al. Predictors of dementia in Parkinson disease: a prospective cohort study. Neurology 2014;83(14):1253-60.

[44] Sinforiani E, Zangaglia R, Manni R, Cristina S, Marchioni E, Nappi G, et al. REM sleep behavior disorder, hallucinations, and cognitive impairment in Parkinson's disease. Mov Disord 2006;21(4):462-6.

[45] Postuma RB, Gagnon JF, Vendette M, Charland K, Montplaisir J. Manifestations of Parkinson disease differ in association with REM sleep behavior disorder. Mov Disord 2008;23(12):1665-72.
[46] Wetter TC, Trenkwalder C, Gershanik O, Hogl B. Polysomnographic measures in Parkinson's disease: a comparison between patients with and without REM sleep disturbances. Wien Klin Wochenschr 2001;113(7-8): 249-53.

[47] Postuma RB, Adler CH, Dugger BN, Hentz JG, Shill HA, Driver-Dunckley E, et al. REM sleep behavior disorder and neuropathology in Parkinson's disease. Mov Disord 2015;30(10):1413-7.

[48] Dauvilliers Y, Winkelmann J. Restless legs syndrome: update on pathogenesis. Curr Opin Pulm Med 2013;19(6):594-600.

[49] Rijsman RM, Schoolderman LF, Rundervoort RS, Louter M. Restless legs syndrome in Parkinson's disease. Parkinsonism Relat Disord 2014;20(Suppl. 1): S5-9.

[50] Pittock SJ, Parrett T, Adler CH, Parisi JE, Dickson DW, Ahlskog JE. Neuropathology of primary restless leg syndrome: absence of specific tau- and alpha-synuclein pathology. Mov Disord 2004;19(6):695-9.

*[51] Garcia-Borreguero D, Odin P, Serrano C. Restless legs syndrome and PD: a review of the evidence for a possible association. Neurology 2003;61(6 Suppl. 3):S49-55.

[52] Ryu JH, Lee MS, Baik JS. Sonographic abnormalities in idiopathic restless legs syndrome (RLS) and RLS in Parkinson's disease. Parkinsonism Relat Disord $2011 ; 17(3): 201-3$.

[53] Turjanski N, Lees AJ, Brooks DJ. Striatal dopaminergic function in restless legs syndrome: 18F-dopa and 11C-raclopride PET studies. Neurology 1999;52(5):932-7.

[54] Eisensehr I, Wetter TC, Linke R, Noachtar S, von Lindeiner H, Gildehaus FJ et al. Normal IPT and IBZM SPECT in drug-naive and levodopa-treated idiopathic restless legs syndrome. Neurology 2001;57(7):1307-9.

[55] Trenkwalder C, Walters AS, Hening WA, Chokroverty S, Antonini A Dhawan V, et al. Positron emission tomographic studies in restless legs syndrome. Mov Disord 1999;14(1):141-5.

[56] Montplaisir J, Boucher S, Poirier G, Lavigne G, Lapierre O, Lesperance P. Clinical, polysomnographic, and genetic characteristics of restless legs syndrome: a study of 133 patients diagnosed with new standard criteria. Mov Disord 1997;12(1):61-5.

[57] Peeraully T, Yong MH, Chokroverty S, Tan EK. Sleep and Parkinson's disease: a review of case-control polysomnography studies. Mov Disord 2012;27(14):1729-37.

[58] Covassin N, Neikrug AB, Liu L, Corey-Bloom J, Loredo JS, Palmer BW, et al. Clinical correlates of periodic limb movements in sleep in Parkinson's disease. J Neurol Sci 2012;316(1-2):131-6.

[59] Happe S, Pirker W, Klosch G, Sauter C, Zeitlhofer J. Periodic leg movements in patients with Parkinson's disease are associated with reduced striatal dopamine transporter binding. J Neurol 2003;250(1):83-6.

[60] Puligheddu M, Figorilli M, Arico D, Raggi A, Marrosu F, Ferri R. Time structure of leg movement activity during sleep in untreated Parkinson disease and effects of dopaminergic treatment. Sleep Med 2014;15(7): $816-24$.

[61] Iranzo A, Valldeoriola F, Santamaria J, Tolosa E, Rumia J. Sleep symptoms and polysomnographic architecture in advanced Parkinson's disease after chronic bilateral subthalamic stimulation. J Neurol Neurosurg Psychiatry 2002;72(5):661-4.

[62] Prudon B, Duncan GW, Khoo TK, Yarnall AJ, Anderson KN. Primary sleep disorder prevalence in patients with newly diagnosed Parkinson's disease. Mov Disord 2014;29(2):259-62.

[63] Simuni T, Caspell-Garcia C, Coffey C, Chahine LM, Lasch S, Oertel WH, et al Correlates of excessive daytime sleepiness in de novo Parkinson's disease: a case control study. Mov Disord 2015;30(10):1371-81.

*[64] Gjerstad MD, Alves G, Wentzel-Larsen T, Aarsland D, Larsen JP. Excessive daytime sleepiness in Parkinson disease: is it the drugs or the disease? Neurology 2006;67(5):853-8.

[65] Fronczek R, Overeem S, Lee SY, Hegeman IM, van Pelt J, van Duinen SG, et al. Hypocretin (orexin) loss in Parkinson's disease. Brain 2007;130(Pt 6): $1577-85$

[66] Videnovic A, Willis GL. Circadian system - a novel diagnostic and therapeutic target in Parkinson's disease? Mov Disord 2016;31(3):260-9.

[67] Videnovic A, Noble C, Reid KJ, Peng J, Turek FW, Marconi A, et al. Circadian melatonin rhythm and excessive daytime sleepiness in Parkinson disease. JAMA Neurol 2014;71(4):463-9.

[68] Zeng J, Wei M, Li T, Chen W, Feng Y, Shi R, et al. Risk of obstructive sleep apnea in Parkinson's disease: a meta-analysis. PLoS One 2013;8(12), e82091.

[69] Maria B, Sophia S, Michalis M, Charalampos L, Andreas P, John ME, et al. Sleep breathing disorders in patients with idiopathic Parkinson's disease. Respir Med 2003;97(10):1151-7.

[70] Chen JC, Tsai TY, Li CY, Hwang JH. Obstructive sleep apnea and risk of Parkinson's disease: a population-based cohort study. J Sleep Res $2015 ; 24(4): 432-7$.

[71] Gjerstad MD, Wentzel-Larsen T, Aarsland D, Larsen JP. Insomnia in Parkinson's disease: frequency and progression over time. J Neurol Neurosurg Psychiatry 2007;78(5):476-9.

[72] Ratti PL, Negre-Pages L, Perez-Lloret S, Manni R, Damier P, Tison F, et al. Subjective sleep dysfunction and insomnia symptoms in Parkinson's disease: insights from a cross-sectional evaluation of the French CoPark cohort. Parkinsonism Relat Disord 2015;21(11):1323-9. 
[73] Chahine LM, Daley J, Horn S, Duda JE, Colcher A, Hurtig H, et al. Association between dopaminergic medications and nocturnal sleep in earlystage Parkinson's disease. Parkinsonism Relat Disord 2013;19(10):859-63.

[74] Do CB, Tung JY, Dorfman E, Kiefer AK, Drabant EM, Francke U, et al. Webbased genome-wide association study identifies two novel loci and a substantial genetic component for Parkinson's disease. PLoS Genet 2011;7(6), e1002141.

[75] Hamza TH, Payami H. The heritability of risk and age at onset of Parkinson's disease after accounting for known genetic risk factors. J Hum Genet 2010;55(4):241-3.

[76] Gan-Or Z, Amshalom I, Kilarski LL, Bar-Shira A, Gana-Weisz M, Mirelman A, et al. Differential effects of severe vs mild GBA mutations on Parkinson disease. Neurology 2015;84(9):880-7.

[77] Gan-Or Z, Leblond CS, Mallett V, Orr-Urtreger A, Dion PA, Rouleau GA. LRRK2 mutations in Parkinson disease; a sex effect or lack thereof? A meta-analysis. Parkinsonism Relat Disord 2015;21(7):778-82.

[78] Goldwurm S, Zini M, Mariani L, Tesei S, Miceli R, Sironi F, et al. Evaluation of LRRK2 G2019S penetrance: relevance for genetic counseling in Parkinson disease. Neurology 2007;68(14):1141-3.

[79] Hulihan MM, Ishihara-Paul L, Kachergus J, Warren L, Amouri R, Elango R, et al. LRRK2 Gly2019Ser penetrance in Arab-Berber patients from Tunisia: a case-control genetic study. Lancet Neurol 2008;7(7):591-4.

[80] Gan-Or Z, Bar-Shira A, Mirelman A, Gurevich T, Kedmi M, Giladi N, et al, LRRK2 and GBA mutations differentially affect the initial presentation of Parkinson disease. Neurogenetics 2010;11(1):121-5.

[81] Lesage S, Durr A, Tazir M, Lohmann E, Leutenegger AL, Janin S, et al. LRRK2 G2019S as a cause of Parkinson's disease in north African Arabs. N Engl Med 2006;354(4):422-3.

[82] Healy DG, Falchi M, O'Sullivan SS, Bonifati V, Durr A, Bressman S, et al. Phenotype, genotype, and worldwide genetic penetrance of LRRK2 associated Parkinson's disease: a case-control study. Lancet Neurol 2008;7(7):583-90.

[83] Sidransky E, Nalls MA, Aasly JO, Aharon-Peretz J, Annesi G, Barbosa ER, et al. Multicenter analysis of glucocerebrosidase mutations in Parkinson's disease. N Engl J Med 2009;361(17):1651-61.

[84] Alcalay RN, Levy OA, Waters CC, Fahn S, Ford B, Kuo SH, et al. Glucocerebrosidase activity in Parkinson's disease with and without GBA mutations. Brain 2015;138(Pt 9):2648-58.

[85] Gegg ME, Burke D, Heales SJ, Cooper JM, Hardy J, Wood NW, et al. Glucocerebrosidase deficiency in substantia nigra of Parkinson disease brains. Ann Neurol 2012;72(3):455-63.

[86] Mata IF, Kachergus JM, Taylor JP, Lincoln S, Aasly J, Lynch T, et al. Lrrk2 pathogenic substitutions in Parkinson's disease. Neurogenetics 2005;6(4): $171-7$.

[87] Polymeropoulos MH, Lavedan C, Leroy E, Ide SE, Dehejia A, Dutra A, et al. Mutation in the alpha-synuclein gene identified in families with Parkinson's disease. Science 1997;276(5321):2045-7.

[88] Kasten M, Klein C. The many faces of alpha-synuclein mutations. Mov Disord 2013;28(6):697-701.

[89] Vilarino-Guell C, Wider C, Ross OA, Dachsel JC, Kachergus JM, Lincoln SJ, et al. VPS35 mutations in Parkinson disease. Am J Hum Genet 2011;89(1): $162-7$.

[90] Funayama M, Ohe K, Amo T, Furuya N, Yamaguchi J, Saiki S, et al. CHCHD2 mutations in autosomal dominant late-onset Parkinson's disease: genome-wide linkage and sequencing study. Lancet Neurol 2015;14(3): $274-82$.

[91] Vilarino-Guell C, Rajput A, Milnerwood AJ, Shah B, Szu-Tu C, Trinh J, et al. DNAJC13 mutations in Parkinson disease. Hum Mol Genet 2014;23(7): 1794-801.

[92] Deng HX, Shi Y, Yang Y, Ahmeti KB, Miller N, Huang C, et al. Identification of TMEM230 mutations in familial Parkinson's disease. Nat Genet 2016:48(7):733-9.

[93] Sudhaman S, Muthane UB, Behari M, Govindappa ST, Juyal RC, Thelma BK Evidence of mutations in RIC3 acetylcholine receptor chaperone as a novel cause of autosomal-dominant Parkinson's disease with non-motor phenotypes. J Med Genet 2016 Aug;53(8):559-66.

[94] Dagan E, Schlesinger I, Ayoub M, Mory A, Nassar M, Kurolap A, et al. The contribution of Niemann-Pick SMPD1 mutations to Parkinson disease in Ashkenazi Jews. Parkinsonism Relat Disord 2015;21(9):1067-71.

[95] Gan-Or Z, Ozelius LJ, Bar-Shira A, Saunders-Pullman R, Mirelman A Kornreich R, et al. The p.L302P mutation in the lysosomal enzyme gene SMPD1 is a risk factor for Parkinson disease. Neurology 2013;80(17): 1606-10.

[96] Kilarski LL, Pearson JP, Newsway V, Majounie E, Knipe MD, Misbahuddin A, et al. Systematic review and UK-based study of PARK2 (parkin), PINK1, PARK7 (DJ-1) and LRRK2 in early-onset Parkinson's disease. Mov Disord 2012;27(12):1522-9.

[97] Foroud T, Uniacke SK, Liu L, Pankratz N, Rudolph A, Halter C, et al. Heterozygosity for a mutation in the parkin gene leads to later onset Parkinson disease. Neurology 2003;60(5):796-801.

[98] Djarmati A, Hedrich K, Svetel M, Lohnau T, Schwinger E, Romac S, et al. Heterozygous PINK1 mutations: a susceptibility factor for Parkinson disease? Mov Disord 2006;21(9):1526-30.
[99] Hedrich K, Djarmati A, Schafer N, Hering R, Wellenbrock C, Weiss PH, et al. DJ-1 (PARK7) mutations are less frequent than Parkin (PARK2) mutations in early-onset Parkinson disease. Neurology 2004;62(3):389-94.

[100] Mencacci NE, Isaias IU, Reich MM, Ganos C, Plagnol V, Polke JM, et al. Parkinson's disease in GTP cyclohydrolase 1 mutation carriers. Brain 2014:137(Pt 9):2480-92.

[101] Lesage S, Drouet V, Majounie E, Deramecourt V, Jacoupy M, Nicolas A, et al. Loss of VPS13C function in autosomal-recessive parkinsonism causes mitochondrial dysfunction and increases PINK1/parkin-dependent mitophagy. Am J Hum Genet 2016;98(3):500-13.

[102] Barber TR, Lawton M, Rolinski M, Evetts S, Baig F, Ruffmann C, et al. Prodromal parkinsonism and neurodegenerative risk stratification in REM sleep behavior disorder. Sleep 2017;40(8).

[103] Brockmann K, Srulijes K, Hauser AK, Schulte C, Csoti I, Gasser T, et al. GBAassociated PD presents with nonmotor characteristics. Neurology 2011:77(3):276-80.

[104] Fereshtehnejad SM, Romenets SR, Anang JB, Latreille V, Gagnon JF, Postuma RB. New clinical subtypes of Parkinson disease and their longitudinal progression: a prospective cohort comparison with other phenotypes. JAMA Neurol 2015;72(8):863-73.

[105] Postuma RB, Gagnon JF, Vendette M, Charland K, Montplaisir J. REM sleep behaviour disorder in Parkinson's disease is associated with specific motor features. J Neurol Neurosurg Psychiatry 2008;79(10):1117-21.

[106] Kumar KR, Ramirez A, Gobel A, Kresojevic N, Svetel M, Lohmann K, et al. Glucocerebrosidase mutations in a Serbian Parkinson's disease population. Eur J Neurol 2013;20(2):402-5.

[107] Alcalay RN, Caccappolo E, Mejia-Santana H, Tang M, Rosado L, Orbe Reilly M, et al. Cognitive performance of GBA mutation carriers with earlyonset PD: the CORE-PD study. Neurology 2012;78(18):1434-40.

[108] Mata IF, Samii A, Schneer SH, Roberts JW, Griffith A, Leis BC, et al. Glucocerebrosidase gene mutations: a risk factor for Lewy body disorders. Arch Neurol 2008;65(3):379-82.

[109] Mitsui J, Matsukawa T, Sasaki H, Yabe I, Matsushima M, Durr A, et al. Variants associated with Gaucher disease in multiple system atrophy. Ann Clin Transl Neurol 2015;2(4):417-26.

[110] Noreau A, Riviere JB, Diab S, Dion PA, Panisset M, Soland V, et al. Glucocerebrosidase mutations in a French-Canadian Parkinson's disease cohort. Can J Neurol Sci 2011;38(5):772-3.

[111] Beavan M, McNeill A, Proukakis C, Hughes DA, Mehta A, Schapira AH. Evolution of prodromal clinical markers of Parkinson disease in a GBA mutation-positive cohort. JAMA Neurol 2015;72(2):201-8.

[112] Nishioka K, Ross OA, Vilarino-Guell C, Cobb SA, Kachergus JM, Mann DM, et al. Glucocerebrosidase mutations in diffuse Lewy body disease. Parkinsonism Relat Disord 2011;17(1):55-7.

[113] Puschmann A. Monogenic Parkinson's disease and parkinsonism: clinical phenotypes and frequencies of known mutations. Parkinsonism Relat Disord 2013;19(4):407-15.

[114] Ruiz-Martinez J, Gorostidi A, Goyenechea E, Alzualde A, Poza JJ Rodriguez F, et al. Olfactory deficits and cardiac 123I-MIBG in Parkinson's disease related to the LRRK2 R1441G and G2019S mutations. Mov Disord 2011;26(11):2026-31.

[115] Saunders-Pullman R, Alcalay RN, Mirelman A, Wang C, Luciano MS, Ortega RA, et al. REM sleep behavior disorder, as assessed by questionnaire, in G2019S LRRK2 mutation PD and carriers. Mov Disord 2015;30(13): 1834-9.

[116] Ehrminger M, Leu-Semenescu S, Cormier F, Corvol JC, Vidailhet M, Debellemaniere E, et al. Sleep aspects on video-polysomnography in LRRK2 mutation carriers. Mov Disord 2015;30(13):1839-43.

[117] Pont-Sunyer C, Iranzo A, Gaig C, Fernandez-Arcos A, Vilas D, Valldeoriola F, et al. Sleep disorders in parkinsonian and nonparkinsonian LRRK2 mutation carriers. PLoS One 2015;10(7), e0132368.

[118] Olson EJ, Boeve BF, Silber MH. Rapid eye movement sleep behaviour disorder: demographic, clinical and laboratory findings in 93 cases. Brain 2000;123(Pt 2):331-9.

[119] Fernandez-Santiago R, Iranzo A, Gaig C, Serradell M, Fernandez M, Pastor P, et al. MAPT association with REM sleep behavior disorder. Neurol Genet 2017;3(1):e131.

[120] Reczek D, Schwake M, Schroder J, Hughes H, Blanz J, Jin X, et al. LIMP-2 is a receptor for lysosomal mannose-6-phosphate-independent targeting of beta-glucocerebrosidase. Cell 2007;131(4):770-83.

[121] Gan-Or Z, Montplaisir JY, Ross JP, Poirier J, Warby SC, Arnulf I, et al. The dementia-associated APOE epsilon4 allele is not associated with rapid eye movement sleep behavior disorder. Neurobiol Aging 2017;49(218):e13-5.

[122] Nishioka K, Ross OA, Ishii K, Kachergus JM, Ishiwata K, Kitagawa M, et al. Expanding the clinical phenotype of SNCA duplication carriers. Mov Disord 2009;24(12):1811-9.

[123] Limousin N, Konofal E, Karroum E, Lohmann E, Theodorou I, Durr A, et al. Restless legs syndrome, rapid eye movement sleep behavior disorder, and hypersomnia in patients with two parkin mutations. Mov Disord 2009;24(13):1970-6.

[124] Theuns J, Verstraeten A, Sleegers K, Wauters E, Gijselinck I, Smolders S, et al. Global investigation and meta-analysis of the C9orf72 (G4C2)n repeat in Parkinson disease. Neurology 2014;83(21):1906-13. 
[125] Daoud H, Postuma RB, Bourassa CV, Rochefort D, Gauthier MT, Montplaisir J, et al. C9orf72 repeat expansions in rapid eye movement sleep behaviour disorder. Can J Neurol Sci 2014;41(6):759-62.

[126] Lubbe SJ, Escott-Price V, Brice A, Gasser T, Hardy J, Heutink P, et al. Is the MC1R variant p.R160W associated with Parkinson's? Ann Neurol 2016;79(1):159-61.

[127] Tell-Marti G, Puig-Butille JA, Potrony M, Badenas C, Mila M, Malvehy J, et al. The MC1R melanoma risk variant p.R160W is associated with Parkinson disease. Ann Neurol 2015;77(5):889-94.

[128] Gan-Or Z, Mohsin N, Girard SL, Montplaisir JY, Ambalavanan A, Strong S, et al. The role of the melanoma gene MC1R in Parkinson disease and REM sleep behavior disorder. Neurobiol Aging 2016;43(180):e7-13.

[129] Moore Ht, Winkelmann J, Lin L, Finn L, Peppard P, Mignot E. Periodic leg movements during sleep are associated with polymorphisms in BTBD9, TOX3/BC034767, MEIS1, MAP2K5/SKOR1, and PTPRD. Sleep 2014;37(9): $1535-42$.

[130] Rye DB. The molecular genetics of restless legs syndrome. Sleep Med Clin 2015;10(3):227-33. xii.

[131] Stefansson H, Rye DB, Hicks A, Petursson H, Ingason A, Thorgeirsson TE, et al. A genetic risk factor for periodic limb movements in sleep. N Engl J Med 2007;357(7):639-47.

[132] Desautels A, Turecki G, Montplaisir J, Brisebois K, Sequeira A, Adam B, et al. Evidence for a genetic association between monoamine oxidase A and restless legs syndrome. Neurology 2002;59(2):215-9.

[133] Winkelmann J, Lichtner P, Schormair B, Uhr M, Hauk S, Stiasny-Kolster K, et al. Variants in the neuronal nitric oxide synthase (nNOS, NOS1) gene are associated with restless legs syndrome. Mov Disord 2008;23(3): 350-8.

[134] Adel S, Djarmati A, Kabakci K, Pichler I, Eskelson C, Lohnau T, et al. Cooccurrence of restless legs syndrome and Parkin mutations in two families. Mov Disord 2006;21(2):258-63.

[135] Redline S, Tishler PV, Tosteson TD, Williamson J, Kump K, Browner I, et al. The familial aggregation of obstructive sleep apnea. Am J Respir Crit Care Med 1995;151(3 Pt 1):682-7.

[136] Patel SR, Goodloe R, De G, Kowgier M, Weng J, Buxbaum SG, et al. Association of genetic loci with sleep apnea in European Americans and African-Americans: the candidate gene association resource (CARe). PLoS One 2012;7(11), e48836.

[137] Wu Y, Cao C, Wu Y, Zhang C, Zhu C, Ying S, et al. TNF-alpha-308G/A polymorphism contributes to obstructive sleep apnea syndrome risk: evidence based on 10 case-control studies. PLoS One 2014;9(9), e106183.

[138] Kaditis AG, Gozal D, Khalyfa A, Kheirandish-Gozal L, Capdevila OS, Gourgoulianis K, et al. Variants in C-reactive protein and IL-6 genes and susceptibility to obstructive sleep apnea in children: a candidate-gene association study in European American and Southeast European populations. Sleep Med 2014;15(2):228-35.

[139] Larkin EK, Patel SR, Goodloe RJ, Li Y, Zhu X, Gray-McGuire C, et al. A candidate gene study of obstructive sleep apnea in European Americans and African Americans. Am J Respir Crit Care Med 2010;182(7): 947-53.

[140] Xu H, Guan J, Yi H, Yin S. A systematic review and meta-analysis of the association between serotonergic gene polymorphisms and obstructive sleep apnea syndrome. PLoS One 2014;9(1), e86460.

[141] Kripke DF, Kline LE, Nievergelt CM, Murray SS, Shadan FF, Dawson A, et al. Genetic variants associated with sleep disorders. Sleep Med 2015;16(2): 217-24.

[142] Baik I, Seo HS, Yoon D, Kim SH, Shin C. Associations of sleep apnea, NRG1 polymorphisms, alcohol consumption, and cerebral white matter hyperintensities: analysis with genome-wide association data. Sleep 2015;38(7): $1137-43$.

[143] Cronin RM, Field JR, Bradford Y, Shaffer CM, Carroll RJ, Mosley JD, et al. Phenome-wide association studies demonstrating pleiotropy of genetic variants within FTO with and without adjustment for body mass index. Front Genet 2014:5:250.

[144] Cade BE, Chen H, Stilp AM, Gleason KJ, Sofer T, Ancoli-Israel S, et al. Genetic associations with obstructive sleep apnea traits in hispanic/latino Americans. Am J Respir Crit Care Med 2016 Oct 1;194(7):886-97.

[145] Yue W, Liu H, Zhang J, Zhang X, Wang X, Liu T, et al. Association study of serotonin transporter gene polymorphisms with obstructive sleep apnea syndrome in Chinese Han population. Sleep 2008;31(11):1535-41.

[146] Qin B, Sun Z, Liang Y, Yang Z, Zhong R. The association of 5-HT2A, 5-HTT, and LEPR polymorphisms with obstructive sleep apnea syndrome: a systematic review and meta-analysis. PLoS One 2014;9(4), e95856.
[147] Khalyfa A, Serpero LD, Kheirandish-Gozal L, Capdevila OS, Gozal D. TNFalpha gene polymorphisms and excessive daytime sleepiness in pediatric obstructive sleep apnea. J Pediatr 2011;158(1):77-82.

[148] Sollars PJ, Pickard GE. The neurobiology of circadian rhythms. Psychiatr Clin North Am 2015;38(4):645-65.

[149] Zhang EE, Liu AC, Hirota T, Miraglia LJ, Welch G, Pongsawakul PY, et al. A genome-wide RNAi screen for modifiers of the circadian clock in human cells. Cell 2009;139(1):199-210.

[150] Chong SY, Ptacek LJ, Fu YH. Genetic insights on sleep schedules: this time, it's PERsonal. Trends Genet 2012;28(12):598-605.

[151] Wager-Smith K, Kay SA. Circadian rhythm genetics: from flies to mice to humans. Nat Genet 2000;26(1):23-7.

[152] Katzenberg D, Young T, Finn L, Lin L, King DP, Takahashi JS, et al. A CLOCK polymorphism associated with human diurnal preference. Sleep 1998;21(6):569-76.

[153] Robilliard DL, Archer SN, Arendt J, Lockley SW, Hack LM, English J, et al. The 3111 Clock gene polymorphism is not associated with sleep and circadian rhythmicity in phenotypically characterized human subjects. J Sleep Res 2002;11(4):305-12.

[154] Benedetti F, Dallaspezia S, Fulgosi MC, Lorenzi C, Serretti A, Barbini B, et al. Actimetric evidence that CLOCK 3111 T/C SNP influences sleep and activity patterns in patients affected by bipolar depression. Am J Med Genet B Neuropsychiatr Genet 2007;144B(5):631-5.

[155] Calati R, Gaspar-Barba E, Yukler A, Serretti A. T3111C clock single nucleotide polymorphism and mood disorders: a meta-analysis. Chronobiol Int 2010;27(4):706-21.

[156] Carpen JD, von Schantz M, Smits M, Skene DJ, Archer SN. A silent polymorphism in the PER1 gene associates with extreme diurnal preference in humans. J Hum Genet 2006;51(12):1122-5.

[157] Parsons MJ, Lester KJ, Barclay NL, Archer SN, Nolan PM, Eley TC, et al. Polymorphisms in the circadian expressed genes PER3 and ARNTL2 are associated with diurnal preference and GNbeta3 with sleep measures. J Sleep Res 2014;23(5):595-604.

[158] Toh KL, Jones CR, He Y, Eide EJ, Hinz WA, Virshup DM, et al. An hPer2 phosphorylation site mutation in familial advanced sleep phase syndrome. Science 2001;291(5506):1040-3.

[159] Xu Y, Padiath QS, Shapiro RE, Jones CR, Wu SC, Saigoh N, et al. Functional consequences of a CKIdelta mutation causing familial advanced sleep phase syndrome. Nature 2005;434(7033):640-4.

[160] Allebrandt KV, Amin N, Muller-Myhsok B, Esko T, Teder-Laving M, Azevedo RV, et al. A K(ATP) channel gene effect on sleep duration: from genome-wide association studies to function in Drosophila. Mol Psychiatry 2013;18(1):122-32.

[161] Jones SE, Tyrrell J, Wood AR, Beaumont RN, Ruth KS, Tuke MA, et al Genome-wide association analyses in 128,266 individuals identifies new morningness and sleep duration loci. PLoS Genet 2016;12(8), e1006125.

[162] Lane JM, Vlasac I, Anderson SG, Kyle SD, Dixon WG, Bechtold DA, et al. Genome-wide association analysis identifies novel loci for chronotype in 100,420 individuals from the UK Biobank. Nat Commun 2016;7:10889.

[163] Gehrman PR, Keenan BT, Byrne EM, Pack AI. Genetics of sleep disorders. Psychiatr Clin North Am 2015;38(4):667-81.

[164] Guilleminault C, Brooks SN. Excessive daytime sleepiness: a challenge for the practising neurologist. Brain 2001;124(Pt 8):1482-91.

[165] Drake CL, Friedman NP, Wright Jr KP, Roth T. Sleep reactivity and insomnia: genetic and environmental influences. Sleep 2011;34(9): 1179-88.

[166] Hublin C, Partinen M, Koskenvuo M, Kaprio J. Heritability and mortality risk of insomnia-related symptoms: a genetic epidemiologic study in a population-based twin cohort. Sleep 2011;34(7):957-64.

[167] Ban HJ, Kim SC, Seo J, Kang HB, Choi JK. Genetic and metabolic characterization of insomnia. PLoS One 2011;6(4), e18455.

[168] Byrne EM, Gehrman PR, Medland SE, Nyholt DR, Heath AC, Madden PA, et al. A genome-wide association study of sleep habits and insomnia. Am J Med Genet B Neuropsychiatr Genet 2013;162B(5):439-51.

[169] Serretti A, Benedetti F, Mandelli L, Lorenzi C, Pirovano A, Colombo C, et al. Genetic dissection of psychopathological symptoms: insomnia in mood disorders and CLOCK gene polymorphism. Am J Med Genet B Neuropsychiatr Genet 2003;121B(1):35-8.

[170] Deuschle M, Schredl M, Schilling C, Wust S, Frank J, Witt SH, et al. Association between a serotonin transporter length polymorphism and primary insomnia. Sleep 2010;33(3):343-7.

[171] Buhr A, Bianchi MT, Baur R, Courtet P, Pignay V, Boulenger JP, et al. Functional characterization of the new human GABA(A) receptor mutation beta3(R192H). Hum Genet 2002;111(2):154-60. 